ADAM DRĄŻEK (Białystok)

\title{
PRZYCZYNEK DO BADAŃ NAD UPADKIEM STRONNICTWA PRACY W WOJEWÓDZTWIE BIAŁOSTOCKIM PO ROKU 1944
}

Po wyzwoleniu Białegostoku przez Armię Czerwoną, 27 i 28 lipca 1944 r. przybyli z Lublina w dwóch grupach pełnomocnicy Polskiego Komitetu Wyzwolenia Narodowego - organu wykonawczego Krajowej Rady Narodowej. Wśród przybyłych byli między innymi Leonard Borkowicz, Jerzy Sztachelski, Edwarda Orłowska, Tadeusz Paszta, Zygmunt Zieliński ${ }^{1}$. Stopniowo do grupy pełnomocników PKWN dołączyli reprezentanci grup społecznych i nurtów politycznych opierających się na deklaracji politycznej Manifestu Lipcowego ${ }^{2}$. W końcu lipca 1944 r. w Białymstoku ujawniła się Delegatura Polskiego Rządu Emigracyjnego w Londynie w osobach Okręgowego Delegata RP Józefa Przybyszewskiego „Grzymały” - sprawu jącego funkcję wojewody białostockiego, Ryszarda Gołębiowskiego „Andrzeja” - nominowanego na prezydenta miasta Białegostoku, oraz inspektora V Inspektoratu Armii Krajowej mjr. Władysława Kaufmana „Bogusława” 3.7 sierpnia 1944 r. wraz z uwięzieniem przez NKWD (radziecki Ludowy Komisariat Spraw Wewnętrznych - Narodnyj Komissariat Wnutriennych Diet) miejscowych przedstawicieli Polski Podziemnej, rozpoczęły się masowe aresztowania polityczne na Białostocczyźnie ${ }^{4}$. Do 15 sierpnia 1944 r. rozwiązano Delegaturę i usta-

1 J. Jelisiejew, Na kierunku biatostockim, Warszawa 1976, s. 236; H. Majecki, Sprawozdania delegatów PKWN z pobytu na Białostocczyźnie w pierwszych dniach po wyzwoleniu spod okupacji hitlerowskiej, „Rocznik Białostocki”, t. IX, 1968-1969, Białystok 1970, s. 371 .

2 A. Dobroński, Białystok. Historia miasta, Białystok 2001, s. 181.

3 T. Żenczykowski, Polska Lubelska 1944, Warszawa 1990, s. 39-40.

4 J. Kułak, Pierwszy rok sowieckiej okupacji, Białystok 1996, s. 28. 
nowione urzędy oraz straż porządkową ${ }^{5}$. Włạdza w Białostockiem została przejęta przez zwolenników Polski Lubelskiej.

Odpowiedzialność pełnomocników PKWN odnosiła się nie tylko do tworzenia hierarchicznych rad narodowych podporządkowanych KRN (organ ustawodawczy pełniący rolę parlamentu), ale również dotyczyła kreowania instytucjonalnych form życia politycznego o charakterze zgodnym $\mathrm{z}$ deklaracją lipcową ${ }^{6} .13$ sierpnia 1944 r. w Białymstoku powstał w oparciu o dawnych członków Komunistycznej Partii Polski, Komunistycznej Partii Zachodniej Białorusi oraz działaczy Organizacji Antyfaszystowskiej Komitet Wojewódzki Polskiej Partii Robotniczej z I sekretarzem Edwardą Orłowską. W skład komitetu weszli ponadto: Feliks Lorek, Władysław Nieśmiałek, Aleksander Litwin, Julian Kubiak, Ewelina Sawicka i Jan Kozłowski. W zebraniu organizacyjnym uczestniczyło 46 osób $^{7}$. Następnie z inicjatywy PPR powołano 28 sierpnia 1944 r. Wojewódzką Radę Narodową w składzie: przewodniczący Jerzy Sztachelski, wiceprzewodniczący Jakub Antoniuk i Władysław Nieśmiałek, sekretarz Tadeusz Jackowski ${ }^{8}$. Sformalizowaną organizację polityczną z początku tworzyła jedynie Polska Partia Robotnicza. Osoby o odmiennej przeszłości politycznej zaangażowane w budowę aparatu administracyjnego stawały się potencjalnymi organizatorami przedwojennych stronnictw politycznych.

1 października 1944 r. ukonstytuował się w Białymstoku posiadający przedwojenne tradycje polityczne Wojewódzki Zarząd Stronnictwa Ludowego z prezesem Jakubem Antoniukiem, wiceprezesami: Edwardem Więcko i Apolinarym Wasilewskim, sekretarzem Aleksandrem Jaźwińskim, skarbnikiem Stanisławem Olejnickim. Do władz wojewódzkich należeli również

5 H. Majecki, Reakcyjne podziemie na Białostocczyźnie w latach 1944-56, Białystok 1979, s. 51.

6 M. Kallas, A. Lityński, Historia ustroju i prawa Polski Ludowej, Warszawa 2000, s. 58-59; Manifest Polskiego Komitetu Wyzwolenia Narodowego, oprac. W. Skrzydło, Lublin 1984, s. 43, w którym czytamy: „Polski Komitet Wyzwolenia Narodowego przystępując do odbudowy państwowości polskiej, deklaruje uroczyście przywrócenie wszystkich swobód demokratycznych (...). Demokratyczne swobody nie moga jednak służyć wrogom demokracji. Organizacje faszystowskie jako antynarodowe tępione będą z całą surowością prawa". W praktyce zapis ten pociągał do odpowiedzialności partie polityczne, które wierne rządowi polskiemu w Londynie nie godziły się na uznanie kształtującej się władzy w Lublinie.

7 H. Gnatowska, PPR w województwie biatostockim 1944-1948. Rozwój i działalność, Warszawa 1979 , s. $16-17$.

8 H. Majecki, M. Gnatowski, Z dziejów walk PPR o zbudowanie i utrwalenie władzy ludowej na Białostocczyźnie w latach 1944-1947, Białystok 1962, s. 19. 
Bolesław Podedworny, Tadeusz Sokólski, Mieczysław Misiuk ${ }^{9}$. Trudno jest ustalić faktyczną ilość członków tworzących SL na Białostocczyźnie, do końca bowiem 1945 r. obowiązywała zasada dobrowolności uczestnictwa w organizacjach powiatowych i zwoływanych zjazdach. Odczuwalny był brak ewidencji organizacyjnej członków ${ }^{10}$. Niewątpliwie należy podkreślić, iż początkowe wpływy Stronnictwa były niewielkie. Wielu działaczy chłopskich uległo oddziaływaniom konspiracyjnego SL „Roch” popierającego program polityczny rządu emigracyjnego w Londynie. Rozłam wśród ludowców dezorientował zwolenników ugrupowania chłopskiego ${ }^{11}$.

Partią polityczną na Białostocczyźnie, która odtworzyła struktury organizacyjne, była Polska Partia Socjalistyczna. Nawiązu jąc do tradycji PPS Wolność Równość Niepodległość powróciła do jednolitej nazwy PPS. Zdaniem Jana Tomickiego, Wojewódzki Komitet Polskiej Partii Socjalistycznej w Białymstoku rozpoczął działalność 17 września 1944 r. w składzie: przewodniczący Włodzimierz Klepacki, sekretarz Bolesław Sokół ${ }^{12}$. Powyższe twierdzenie podważył Henryk Majecki, uznając skierowanie Andrzeja Krzewniaka w połowie grudnia 1944 r. przez Centralny Komitet Wykonawczy PPS do pracy partyjnej w białostockiej organizacji, za właściwy moment utworzenia tymczasowego Wojewódzkiego Komitetu Robotniczego Polskiej Partii Socjalistycznej13. Szeregi partyjne socjalistów do końca 1944 r. liczyły około 300 członków $^{14}$.

Do końca czerwca 1945 r. nie istniała organizacja wojewódzka Stronnictwa Demokratycznego na Białostocczyźnie. Idee i założenia programowe SD w województwie białostockim podjęła nieliczna grupa lewicowej inteligencji w znacznej części udzielająca się w tworzenie aparatu rad narodowych wszystkich szczebli ${ }^{15}$. W pierwszych dniach lipca $1945 \mathrm{r}$. inteligencja ta zebrała

9 R. Halaba, Stronnictwo Ludowe 1944-1946. Niektóre problemy rozwoju organizacyjnego i dziatalności politycznej, Warszawa 1966, s. 50.

10 R. Halaba, Dziatalność SL w pierwszych latach Polski Ludowej, w: Z najnowszych dziejów Polski 1939-1947, pod red. Wł. Góry i J. Gołębiowskiego, Warszawa 1961, s. 398.

11 H. Majecki, Białostocczyzna w pierwszych latach władzy ludowej 1944-1948, Warszawa 1977 , s. 41-42.

12 J. Tomicki, Polska Partia Socjalistyczna 1892-1948, Warszawa 1983, s. 437.

13 H. Majecki, Powstanie, rozwój organizacyjny oraz główne problemy dziatalności białostockiej wojewódzkiej organizacji PPS w latach 1944-1948, „Rocznik Białostocki”, t. XIII, Warszawa 1976, s. 114.

14 A. Reiss, $Z$ problemów odbudowy i rozwoju organizacyjnego PPS (1944-1946), Warszawa 1971 , s. 100 .

15 Z. Kummer, Stronnictwo Demokratyczne na Białostocczyźnie (1944-1947), „Zeszyty Historyczno-Polityczne SD" 1977, z. 12, s. 59. 
się w mieszkaniu Witolda Wenclika i tam, jak wspominał jeden z założycieli Stronnictwa - Leon Szestakowski, „złożyliśmy podpisy na dokumencie, dostaliśmy statut i nic więcej" ${ }^{16}$. Dopiero 19 lipca 1945 r. odbyło się formalne spotkanie organizacyjne, na którym powołano Tymczasowy Zarząd Wojewódzki Stronnictwa Demokratycznego w Białymstoku. Przewodniczącym został Witold Wenclik, członkami Zarządu Wykonawczego organizacji wojewódzkiej demokratów: Eugenia Krassowska, Wacław Białkowski i Antoni Topolewicz ${ }^{17}$. SD na Białostocczyźnie pod koniec 1945 r. było stosunkowo nieduże, liczyło około 100 członków ${ }^{18}$.

Ugrupowaniem politycznym, które na jesieni 1945 r. utworzyło w Białostockiem strukturę wojewódzką było Polskie Stronnictwo Ludowe. Formacja Stanisława Mikołajczyka od zalegalizowania w kraju 22 sierpnia 1945 r. pod nazwą PSL, aż do zorganizowania w październiku 1945 r. Zarządu Wojewódzkiego w Białymstoku była najbardziej dynamiczną partią. W krótkim okresie objęła zasięgiem działania ważniejsze miasta w województwie: Augustów, Białystok, Bielsk Podlaski, Grajewo, Łomżę i Suwałki. Na początku 1946 r. liczba członków Polskiego Stronnictwa Ludowego na Białostocczyźnie dochodziła do 5 tysięcy osób, a według danych Naczelnego Komitetu Wykonawczego PSL wynosiła około 10 tysięcy ${ }^{19}$.

Ostatnią partią reaktywu jącą przedwojenną działalność polityczną było Stronnictwo Pracy ${ }^{20}$. W lipcu 1945 r. z chwilą powrotu do kraju Ka-

16 E. Szulborski, SD na Białostocczyźnie w latach 1945-1975, maszynopis niepublikowany, Białystok 1979, s. 27.

17 Archiwum Państwowe w Białymstoku (dalej APB), Protokół z I Zjazdu (z załącznikami) SD Wojewódzkiego Komitetu w Białymstoku 1948, sygn. 1: Protokół nr 1 z posiedzenia organizacy jnego okręgu białostockiego odbytego dnia 19.VII.1945 r. w Białymstoku w lokalu Urzędu Wojewódzkiego, k. 1.

18 APB, Stronnictwo Demokratyczne w województwie białostockim w latach 1944-1975, monografia Eugeniusza Szulborskiego, sygn. 113: E. Szulborski, Stronnictwo..., tabela nr 30: Rozwój organizacyjny Stronnictwa Demokratycznego województwa Białostockiego w latach 1944-1975, k. 119.

19 R. Turkowski, Polskie Stronnictwo Ludowe w obronie demokracji 1945-1949, Warszawa 1992, s. 74; H. Majecki, M. Gnatowski, Z dziejów walk PPR..., Białystok 1962, s. 59.

20 H. Przybylski, Chrześcijańska Demokracja i Narodowa Partia Robotnicza w latach 1926-1937, Warszawa 1980, s. 340-341. Ugrupowanie chrześcijańskie genezą sięgało II Rzeczypospolitej, powstało 10 października 1937 r. z połączenia Narodowej Partii Robotniczej, Chrześcijańskiej Demokracji i Związku Hallerczyków. Prezesem Rady Naczelnej został generał Józef Haller, wiceprezesami: pułkownik Izydor Modelski, Kazimierz Beye oraz Ignacy Sikora. Na czele Zarządu Głównego stanął nieobecny w kraju Wojciech Korfanty, a jego obowiązki faktycznie pełnił Karol Popiel. Nowej partii poparcia udzielili biskupi katoliccy: Henryk Przeździecki, Paweł Kubicki, Stanisław Łukomski i Antoni Szlagowski, który mszą zainaugurował działalność Stronnictwa. 
rola Popiela, prezesa prawowitego SP, uaktywniła się grupa secesjonistów Zygmunta Felczaka i Feliksa Widy-Wirskiego, którzy jeszcze w 1943 r. dokonali rozłamu w organizacji macierzystej przyjmując nazwę Stronnictwa Zrywu Narodowego ${ }^{21}$. Rozłamowcy nawiązali współpracę z PPR i co najmniej od jesieni $1944 \mathrm{r}$. pozostawali w ścisłym kontakcie $\mathrm{z}$ partią komunistyczną $^{22}$.

W początkowych planach tzw. „komisji trzech”: z Władysławem Gomułką (Polska Partia Robotnicza), Stanisławem Szwalbe (Polska Partia Socjalistyczna) i Władysławem Kiernikiem (Stronnictwo Ludowe) w składzie, dopuszczającej ruchy polityczne do systemu partyjnego w nowej Polsce, postulowano połączenie partii chadeckiej i Stronnictwa Demokratycznego w jedną organizację polityczną o nazwie Chrześcijańsko-Społecznego Stronnictwa Demokratycznego lub Chrześcijańsko-Demokratycznego Stronnictwa i włączenie jako czwartego członu do koalicji wspierającej budowę ustroju ludowego ${ }^{23}$. Odwołania Popiela sprawiły, iż zrezygnowano z "automatycznej” unifikacji SP i SD, uzależniając zgodę na legalną działalność Stronnictwa Pracy od porozumienia zwolenników Popiela i aktywistów Zrywu Felczaka i Widy-Wirskiego ${ }^{24}$. Sytuacja była trudna, członkowie Stronnictwa Zrywu Narodowego od ujawnienia działalności deklarowali „gotowość wsparcia państwa w jego pracach ogólnopaństwowych oraz zacieśniania współpracy z partiami tworzącymi nowe demokratyczne władze" ${ }^{25}$, podczas gdy Stronnictwo Pracy pretendowało do bycia niezależną od jakichkolwiek układów siłą polityczną ${ }^{26}$.

14 listopada 1945 r. „komisja trzech”, wykorzystując groźbę uznania grupy Zrywu za jedynych spadkobierców politycznych Stronnictwa Pracy,

21 A. Paczkowski, Zdobycie władzy 1945-1947, Warszawa 1993, s. 36.

22 A. Andrusiewicz, Stronnictwo Pracy 1937-1950: ze studiów nad dziejami najnowszymi chadecji w Polsce, Warszawa 1988, s. 369; M. Piotrowski, Stuźba idei czy serwilizm? Zygmunt Felczak i Feliks Widy-Wirski w najnowszych dziejach Polski, Lublin 1994, s. $215-216$.

23 A. Czubiński, Stronnictwo Demokratyczne (1937-1989). Zarys dziejów, Poznań 1998, s. 156.

24 J. Wrona, System partyjny w Polsce 1944-1950. Miejsce - funkcje - relacje partii politycznych w warunkach budowy i utrwalania systemu totalitarnego, Lublin 1997, s. 173.

25 J. Tobiasz, Stanowisko Stronnictwa Pracy oraz Kościoła Katolickiego wobec węzłowych problemów Polski Ludowej 1945-1947, w: O utrwalenie władzy ludowej w Polsce 1944-1948, pod red. Wł. Górego, R. Halaby, Warszawa 1982, s. 77.

26 B. Fijałkowska, T. Godlewski, Polskie dylematy polityczne 1939-1995, Olsztyn 1996, s. 16. 
nakłoniła członków SP skupionych wokół Karola Popiela do jedności w ugrupowaniu chrześcijańskim ${ }^{27}$. Za cenę przyznania połowy miejsc w Głównym Komitecie Wykonawczym nastąpiła pod koniec 1945 r. legalizacja Stronnictwa Pracy. Prezesem Tymczasowego Zarządu Głównego został Karol Popiel, wiceprezesami: Józef Kwasiborski (z grupy londyńskiej), Zygmunt Felczak, Feliks Widy-Wirski i Tadeusz Michejda (wszyscy z grupy Zryw). Równocześnie $\mathrm{z}$ ramienia SP weszło 16 posłów do KRN, w tym 9 z grupy Zryw ${ }^{28}$. Powyższe działanie zgodne było $\mathrm{z}$ oczekiwaniami partii komunistycznej. W planach PPR sprawą ogromnej wagi stało się przyciągnięcie do władzy ludowej inteligencji aprobującej katolicką naukę społeczną i „zneutralizowanie części kleru" przez zróżnicowanie poglądów ludzi związanych z Kościołem katolickim ${ }^{29}$. Uderzenie w grupę działaczy chadeckich Popiela było pośrednio uderzeniem w hierarchię kościelną, której zaufaniem cieszył się przywódca Stronnictwa Pracy ${ }^{30}$.

Stronnictwo Pracy w województwie białostockim reaktywowało działalność polityczną najpóźniej ze wszystkich organizacji wojewódzkich. 14 lutego 1946 r. utworzony został Zarząd Wojewódzki SP w Białymstoku z prezesem Władysławem Filipowiczem, wiceprezesami Franciszkiem Chańko i Kazimierzem Kosińskim, sekretarzem Kazimierzem Surowińskim oraz skarbnikiem Leonem Łukaszewiczem ${ }^{31}$. Większość członków białostockiej chadecji polityczną aktywność rozpoczynała w Stronnictwie Narodowym ${ }^{32}$. W swoich szeregach skupiała przeważnie „elementy byłej Chrześcijańskiej Demokracji oraz elementy mniej lub bardziej demokratyczne. Niewątpliwie wśród mas drobnomieszczańskich i inteligencji Stronnictwo Pracy stanowiło poważną konkurencję SD. SP oblicza politycznego na terenie województwa nie

27 J. M. Majchrowski, Stronnictwo Pracy. Działalność polityczna i koncepcje programowe 1937-1945, Warszawa - Kraków 1979, s. 75.

28 K. Popiel, Od Brześcia do „Polonii”, Londyn 1967, s. 138; Wł. Góra, Polska Ludowa 1944-1984, Lublin 1986, s. 138.

29 F. Widy-Wirski, Nie każdemu pokoleniu dane byto to przeżyć, w: Takie byty początki, pod red. Wł. Góry, H. Kamińskiej, J. Paszty, Warszawa 1965, s. 644.

30 A. Garlicki, Stalinizm, Warszawa 1993, s. 10.

31 APB, Komitet Wojewódzki Polskiej Partii Robotniczej w Białymstoku: Sekretariat. Protokoły wspólnych narad władz i aktywu PPR, PPS, SL i SD woj. białostockiego (Wojewódzka Międzypartyjna Komisja Porozumiewawcza, Wojewódzka „3” Polityczna) 1945-1948, sygn. 12: Do Wojewódzkiej Komisji Porozumiewawczej Stronnictw Demokratycznych - Stronnictwo Pracy Zarząd Główny w Białymstoku, k. 38.

32 A. Andrusiewicz, op. cit., s. 253. 
ujawnia, zachowując pewną rezerwę" ${ }^{33}$. Wy jątkiem były zjazdy wojewódzkie, na których dochodziło do wystąpień antykomunistycznych oraz ostrych sporów między zwolennikami Zrywu i sympatykami Popiela ${ }^{34}$.

We władzach wojewódzkich białostockiego Stronnictwa Pracy większość członków uznawała idee polityczne głoszone przez Karola Popiela. Prezes SP postulował parlamentaryzm oparty na klasycznej zasadzie trójpodziału władzy, której cele i metody rządzenia nie powinny były różnić się od moralności chrześcijańskiej. Opowiadał się za samorządnością pracowników i pracodawców skupionych w Naczelnej Radzie Gospodarczo-Społecznej, koordynującej przepływ kapitału ludzkiego i materialnego oraz łagodzącej wynikające z polityki gospodarczej państwa nierówności społeczne. Był również zwolennikiem interwencjonizmu państwowego, ale tylko odnośnie tych zadań, którym inicjatywa prywatna nie mogła sprostać. Wypowiadał się przeciwko kolektywizacji utożsamianej z biurokracją, biernością i brakiem inicjatywy obywatelskiej. W sferze oświatowo-kulturalnej postulował powszechny i bezpłatny system nauczania wszystkich szczebli oraz wyrugowanie z kultury narodowej kosmopolityzmu ${ }^{35}$. Stronnicy Zygmunta Felczaka i Feliksa Widy-Wirskiego dominu jący w województwach: poznańskim, bydgoskim i szczecińskim traktowali przyszły ustrój przede wszystkim jako narzędzie skutecznego likwidowania „niżu cywilizacyjnego" Polski. Według sympatyków tej części Stronnictwa Pracy jednostka winna realizować nakreślone przez państwo cele narodowe, które w konsekwencji mają doprowadzić do powstania bezklasowej wspólnoty ${ }^{36}$.

Do końca lutego 1946 r. powstał Zarząd Grodzki w Białymstoku i Zarządy Powiatowe w Łomży, Sokółce i Bielsku Podlaskim. Stan członków organizacji wojewódzkiej SP w Białymstoku odpowiadał 200-220 osobom. Była to liczba niewielka w porównaniu z 7 tysiącami członków zgromadzonych w 307 kołach w 1927 r. w województwie białostockim ${ }^{37}$. Partia chrześcijańska miała nieduże wpływy w społeczeństwie, gdyż wielu jej zwolenników

33 APB, Urząd Wojewódzki Białostocki 1944-1950. Miesięczne sprawozdania sytuacyjne Wydziału Społeczno-Politycznego 1945-1947, sygn. 483: Sprawozdania sytuacyjne Wydziału Społeczno-Politycznego za miesiąc maj 1946 r. - Białystok 8 czerwca 1946 r., k. 115 .

34 W. Bujak, Historia Stronnictwa Pracy 1937-1946-1950, Warszawa 1988, s. 157-158 .

35 K. Przybysz, Polska myśl polityczna 1939-1945, Warszawa 2000, s. 45-47.

36 W. Bujak, op. cit., s. 120-121.

37 Ibidem, s. 60; H. Majecki, Chrześcijańska demokracja w województwie białostockim w latach 1918-1935, „Studia Podlaskie”, t. III, Białystok 1991, s. 64. 
poparło uniwersalistyczny program polityczny Polskiego Stronnictwa Ludowego Mikołajczyka, w którym zawarte były również tezy z nauki społecznej Kościoła katolickiego. Struktura wojewódzka Stronnictwa Pracy w Białymstoku do momentu zakończenia w 1950 r. działalności politycznej nie wyszła już poza miasta Białostocczyzny, w których SP rozpoczynało powojenną aktywność ${ }^{38}$.

W okresie powstawania organizacji wojewódzkiej i zarządów powiatowych Stronnictwa Pracy, w lutym 1946 r. na Białostocczyźnie rozpoczęły działalność powołane przez Międzypartyjną Komisję Porozumiewawczą Stronnictw Demokratycznych: PPR, PPS, SL i SD wspólne w województwie, powiatach i miastach komitety do spraw głosowania ludowego. Ich celem miało być propagowanie referendum i trzykrotnej pozytywnej odpowiedzi na następujące pytania:

1. Czy jesteś za zniesieniem Senatu?

2. Czy chcesz utrwalenia w przyszłej Konstytucji ustroju gospodarczego wprowadzonego przez reformę rolną i unarodowienie podstawowych gałęzi gospodarki krajowej, przy zachowaniu ustawowych uprawnień inicjatywy prywatnej?

3. Czy chcesz utrwalenia zachodnich granic państwa polskiego na Bałtyku, Odrze i Nysie Łużyckiej? ${ }^{39}$

Wojewódzki Komitet Wyborczy do spraw głosowania ludowego w Białymstoku zorganizował w Teatrze Miejskim wiec poparcia referendum. Zaapelował do ogółu obywateli o akceptację pytań referendalnych. Jednocześnie napiętnował Polskie Stronnictwo Ludowe i Stronnictwo Pracy za brak wsparcia inicjatywy stronnictw demokratycznych. PSL i SP uzasadniły nieobecność w akcji zorganizowanej przez PPR, PPS, SL i SD brakiem centralnej instrukcji zezwalającej na przystąpienie do projektu czterech partii ${ }^{40}$. W referendum z 30 czerwca 1946 r. Stronnictwo Pracy zajęło stanowisko negatywne wobec odpowiedzi na pytanie o zniesienie Senatu, uznając dwa kolejne za możliwe do przyjęcia ${ }^{41}$.

38 H. Majecki, Początki władzy ludowej na Białostocczyźnie 1944-1947, Lublin 1969, s. 123.

39 T. Marczak, Propaganda polityczna stronnictw przed referendum z 30. VI.1946 r., Wrocław 1986, s. 213; J. Eisler, Zarys dziejów politycznych Polski 1944-1989, Warszawa 1992 , s. 28.

40 APB, Wojewódzki Urząd Informacji i Propagandy w Białymstoku 1944-47, sygn. 6: Sprawozdania miesięczne WUIiP za okres: styczeń-marzec 1946 r. - Ogólna ocena sytuacji z lutego 1946 r., k. 104.

41 APB, Wojewódzki Urząd Informacji..., sygn. 7: Sprawozdania miesięczne WUIiP za okres od kwietnia do czerwca 1946 r. - Działalność stronnictw politycznych, k. 233. 
Według oficjalnych wyników ogłoszonych 12 lipca 1946 r. w skali kraju na 13.160.451 uprawnionych w referendum wzięło udział $85,3 \%$. Na pytanie pierwsze "tak" odpowiedziało $68,2 \%$ osób, na pytanie drugie odpowiedziało „tak” $77,1 \%$ osób, na trzecie odpowiedziało „tak” $91,4 \%$ osób ${ }^{42}$. W województwie białostockim wyniki referendum okazały się również pomyślne dla Bloku Stronnictw Demokratycznych. Na ogólną liczbę 503.471 uprawnionych udział w referendum wzięło $91 \%$. Oddano 432.649 głosów ważnych. Na pierwsze pytanie odpowiedziało „tak" 70,9\% głosu jących, na drugie pytanie odpowiedziało „tak" 73,6\% osób, a na trzecie dało twierdzącą odpowiedź $97,2 \%$ osób $^{43}$.

Po czerwcowym referendum ludowym z 1946 r. w Stronnictwie Pracy odnowił się wśród członków podział na zwolenników Karola Popiela i popierających Feliksa Widy-Wirskiego. Sympatyków ostatniej grupy przybyło na tyle, że możliwe stało się sabotowanie wewnątrzpartyjnych zarządzeń Głównego Komitetu Wykonawczego SP, które miały usprawnić działalność partii chrześcijańskiej. Fiaskiem chociażby zakończyła się próba zwołania przez Popiela ogólnopolskiego Kongresu Stronnictwa Pracy, na którym miał nastąpić powrót Stronnictwa do koncepcji programowych sprzed „zjednoczenia". 18 lipca 1946 r. Zarząd Główny SP podjął decyzję o zawieszeniu działalności politycznej stronnictwa. Postanowienie doręczono KRN, premierowi oraz władzom naczelnym ugrupowań ${ }^{44}$.

25 lipca 1946 r. Wojewódzki Komitet Stronnictwa Pracy w Białymstoku, stosownie do zarządzeń władz centralnych, zawiesił działalność swych struktur, powiadamiając o tym PPR, PPS, SL, SD i PSL w województwie ${ }^{45}$. Jednocześnie został powołany Tymczasowy Zarząd $z$ byłym sekretarzem WK SP, Kazimierzem Surowińskim, który miał zabezpieczyć majątek Stronnictwa i dokonać weryfikacji liczby członków ${ }^{46} .13$ sierpnia 1946 r. frakcjoniści z Głównego Komitetu Wykonawczego Stronnictwa Pracy na czele z Feliksem Widy-Wirskim i Tadeuszem Michejdą wznowili działalność, wydając wytyczne odwieszające decyzję Zarządu Głównego SP zawieszającą

42 O. Halecki, Historia Polski, Lublin 1992, s. 304-305.

43 H. Gnatowska, Biatostocka wojewódzka organizacja PPR w referendum ludowym $i$ wyborach do Sejmu Ustawodawczego, "Rocznik Białostocki”, t. XV, Warszawa 1981, s. 124 .

44 K. Popiel, op. cit., s. 207.

45 APB, Komitet Wojewódzki PPR w Białymstoku. Sekretariat. Materiały dotyczące stronnictw politycznych, sygn. 19: Do Zarządu Wojewódzkiego PPR w Białymstoku, k. 19.

46 APB, Urząd Wojewódzki..., sygn. 483: Sprawozdania Wydziału Społeczno-Politycznego za miesiąc lipiec 1946 r. - Białystok, 19 lipca 1946 r., k. 156. 
pracę Stronnictwa. Pismo prezesa Stronnictwa Pracy F. Widy-Wirskiego rozesłano do wszystkich Tymczasowych Zarządów Wojewódzkich nakazując byłym członkom Stronnictwa podjęcie aktywności partyjnej ${ }^{47}$. W województwie białostockim pod koniec sierpnia 1946 r. pełniącym obowiązki prezesa SP został do czasu ukonstytuowania się nowego kierownictwa Kazimierz Surowiński, sekretarzem zaś Zygmunt Stankiewicz ${ }^{48}$. Stronnictwo Pracy nie było już $w$ stanie $w$ pełni odtworzyć organizacji terenowych. W województwie białostockim „zorganizowało zaledwie koła w czterech powiatach" 49. Partia chrześcijańska wznawiała działalność polityczną z nowym programem politycznym zbliżonym do koncepcji wcześniej głoszonych przez członków Stronnictwa Zrywu Narodowego. Zapewne dwie wykluczające się decyzje stały się przyczyną nieprzystąpienia wielu członków do SP.

Wybory do Sejmu z 19 stycznia 1947 r. potwierdziły marginalizację Stronnictwa Pracy. Według oficjalnych wyników, SP w skali kraju uzyskało 530.979 głosów $\left(4,7 \%\right.$ ), co równało się 12 mandatom poselskim ${ }^{50}$. W województwie białostockim wyniki wyborcze dla SP były jeszcze gorsze. W okręgu wyborczym nr 19, obejmu jącym obszar: Białystok, Bialystok - powiat, Bielsk Podlaski, Sokółka, Wysokie Mazowieckie, na chadecję zagłosowało 7.798 osób (3\%). W okręgu wyborczym nr 20, składającym się z Augustowa, Ełku, Gołdapi, Grajewa, Łomży, Olecka i Suwałk, Stronnictwo Pracy nie uzyskało poparcia wyborczego $z$ racji niewystawienia kandydatów. Ostateczny bilans wyborów do Sejmu zamykał się brakiem przedstawicieli partii chrześcijańskiej w parlamencie. Na 8 mandatów poselskich przyznanych dla okręgu wyborczego nr 19 z siedzibą w Białymstoku, siedem przypadło delegatom Bloku Demokratycznego, a tylko jeden przypadł PSL. W okręgu wyborczym nr 20 w Ełku wszystkie pięć mandatów poselskich przydzielono kandydatom demokratycznym ${ }^{51}$. Słabość białostockiej organi-

47 A. Andrusiewicz, op. cit., s. 295; APB, KW PPR w Białymstoku..., sygn. 19: Odezwa Stronnictwa Pracy, k. 20.

48 M. Gnatowski, Specyficzne uwarunkowania ksztattowania się wtadzy ludowej w regionie biatostockim (lipiec 1944-styczen 1947), w: Studia nad procesami rozwoju regionu biatostockiego w 40-leciu PRL, pod red. M. Gnatowskiego, W. Nieciuńskiego, W. Pukniela, Białystok 1985, s. 24.

49 APB, Urząd..., sygn. 483: Sprawozdania sytuacyjne Wydziału Społeczno-Politycznego za miesiąc październik 1946 r. - Białystok, 28 listopada 1946 r., k. 201.

50 J. Wrona, Kampania wyborcza do Sejmu Ustawodawczego 19 stycznia 1947, Warszawa 1999, s. 40.

51 APB, Protokoły posiedzeń Komisji Historycznej SD Wojewódzkiego Komitetu w Białymstoku dotyczące konkursu na pamiętniki i wspomnienia działaczy SD, t. I, sygn. 110: Z. Kummer, Stronnictwo Demokratyczne na Białostocczyźnie w życiu politycznym (1944-1947), Białystok 1979, k. 35-36. 
zacji wojewódzkiej Stronnictwa Pracy widoczna była również w skromnej reprezentacji członków stronnictwa biorących udział w pracach rad narodowych. Do końca 1948 r. SP posiadało tylko dwóch radnych w Wojewódzkiej Radzie Narodowej oraz dwóch przedstawicieli w Powiatowych Radach Narodowych. W Gminnych Radach Narodowych od początku działalności nie miało członków ${ }^{52}$.

Zjednoczenie 15 grudnia 1948 r. partii robotniczych PPR i PPS w Polską Zjednoczoną Partię Robotniczą uważa się za moment kończący formowanie systemu komunistycznego w Polsce. Rok 1950 ostatecznie zamykał proces kształtowania się systemu partyjnego Polski Ludowej53. W listopadzie 1949 r. rozbite Polskie Stronnictwo Ludowe połączyło się ze Stronnictwem Ludowym, tworząc Zjednoczone Stronnictwo Ludowe. Natomiast w lipcu 1950 r. Stronnictwo Demokratyczne wchłonęło część członków z rozwiązanego Stronnictwa Pracy. Ugrupowania reprezentowały grupy społeczne robotników, chłopów i inteligencję, wspomagając w aspiracjach politycznych wyraziciela wszystkich kategorii społecznych, partię komunistyczną ${ }^{54}$.

Do rozmów nad fuzją demokratów z chadekami powrócono w 1949 r. Przywódcy PZPR wyrażali opinię, że „Państwa demokracji ludowej zmierzać będą do całkowitej konsolidacji narodowej przez likwidację stronnictw w okresie przejściowym, będących formacjami sojuszniczymi, swoistymi pomostami do mas. Na odcinku mieszczańskim dublują się chociażby SP i SD" 55. Postulowano przekształcenie w ramach monopartii komunistycznej: chadecji w wydział rzemieślniczy, stronnictw chłopskich w wydział chłopski, a SD w swego rodzaju wydział inteligencki ${ }^{56}$. „Jedno było pewne, PZPR nie chciała tolerować Stronnictwa Pracy, które miało ambicje działania na terenie robotniczym, a dla »obsługi « rzemiosła, resztek prywatnej inicjatywy w handlu czy inteligencji, istniało już powolne komunistycznym ideom i co najważniejsze »bezwyznaniowe« Stronnictwo Demokra-

52 APB, Stronnictwo Demokratyczne..., sygn. 113: E. Szulborski, op. cit., tabela 29: Skład polityczny WRN w Białymstoku 1944-1948. Liczba członków poszczególnych partii w Radach Narodowych; tabela 30: Skład polityczny PRN w województwie w latach 1944-1948. Liczba członków partii, k. 90; tabela 31: Przynależność partyjna radnych GRN województwa białostockiego z lat 1945-1948, k. 91.

53 A. Czubiński, J. Topolski, Historia Polski, Wrocław 1988, s. 565.

54 H. Dylągowa, Historia Polski 1795-1990, Lublin 2000, s. 206.

55 H. Minc, Niektóre zagadnienia demokracji ludowej w świetle leninowsko-stalinowskiej nauki o dyktaturze proletariatu, "Nowe Drogi” 1949, nr 6, s. 102-103; W. Bujak, op. cit., s. 239.

56 J. Wrona, System..., s. 307. 
tyczne" 57 . Ostatni przymiot ważny był o tyle, że nie stanowił konkurencji wobec eksportowanej ze Związku Radzieckiego zasady komunizmu dyktatury proletariatu. Zasada ta tworzyła odmienną hierarchię stosunków społeczno-politycznych, nazywała religię sferą mistycznych wzlotów, „drogą myślową ludzi, którzy straciwszy wiarę w historię i postęp, szukają ideału poza światem" 58 .

Na Białostocczyźnie organizacja wojewódzka Stronnictwa Pracy pod koniec 1948 r. liczyła 223 członków, a w połowie 1950 r. należało do niej 213 osób ${ }^{59}$. Analizując bazę członkowską białostockiej WK SP z 1950 r. można zauważyć, że była zdominowana w $43 \%$ przez robotników pracujących najczęściej w zawodzie elektromontera budowlanego. Prywatni przedsiębiorcy i drobne rzemiosło stanowiło $28 \%$ wszystkich członków Stronnictwa. W przewadze byli to szewcy i krawcy. Administracja reprezentowana była przez $13 \%$ stanu osobowego SP, natomiast $9 \%$ członków związanych było $\mathrm{z}$ rolnictwem. Pozostałą strukturę tworzyli stosunkowo najmniej liczni nauczyciele i uczniowie ${ }^{60}$. Analiza ilościowa białostockiej formacji politycznej SP zdaje się potwierdzać dążenia chadecji do objęcia wpływami ludności miejskiej, zwłaszcza pracowników fizycznych i prywatnych przedsiębiorców.

Polityczna fuzja Stronnictwa Pracy ze Stronnictwem Demokratycznym rozpoczynała się faktycznie od ujednolicenia celów wpisanych w program działania obu partii. SD na II Kongresie (30 IX-2 X 1949 r.) zobligowane do scalenia swego naczelnego hasła programowego - demokracji z socjalizmem, dopracowało się demokracji społecznej. Jednocześnie uznało kierowniczą rolę PZPR, godząc się na towarzyszenie klasie robotniczej w budowie socjalizmu w Polsce Ludowej61. SP zmierzało programowo do podobnych rozwiązań politycznych. Ujmując pojęcie chrześcijaństwa jako tożsamego z demokracją ludową, sprowadzało wykładnię katolickiej nauki społecznej do spraw czysto socjalnych ${ }^{62}$. Obydwa ugrupowania zatraciły tożsamość idei, z potrzeby których pierwotnie powstały. Unifikacja Stronnictwa Pracy ze

57 A. Paczkowski, Pót wieku dziejów Polski 1939-1989, Warszawa 2000, s. 249.

58 J. Kossak, Bunt na kolanach, Warszawa 1960, s. 64.

59 W. Bujak, op. cit., s. 220-221.

60 Własna analiza ilościowa na podstawie: APB, Protokół przejęcia przez Wojewódzki Komitet SD majątku Stronnictwa Pracy Wojewódzkiego Komitetu w Białymstoku 1950, sygn. 157: Wykaz członków byłego Stronnictwa Pracy, k. 12-14.

61 Podstawowe fakty $z$ historii Stronnictwa Demokratycznego, Warszawa 1960, s. 44.

62 L. Dyczewski, Kultura polska w procesie przemian, Lublin 1993, s. 79. 
Stronnictwem Demokratycznym przy konsolidacji sceny politycznej - zjednoczenia partii robotniczych w PZPR i scalenia stronnictw chłopskich w ZSL - wydawała się kwestią niedługiego czasu.

4 czerwca 1950 r. rozpoczęły się na szczeblu centralnym inspirowane przez komunistów poufne rozmowy między przedstawicielami SP i SD. Stronnictwo Demokratyczne reprezentował sekretarz generalny Zygmunt Moskwa, z ramienia Stronnictwa Pracy występowali: prezes Rady Naczelnej Stefan Brzeziński oraz przewodniczący Głównego Komitetu Wykonawczego Tadeusz Michejda. Na spotkaniu ustalono, że 9 lipca 1950 r. chadecja zostanie rozwiązana, a wybrani jej członkowie dołączą do struktur naczelnych partii demokratycznej63. Leon Chajn, jeden z liderów CK SD i jednocześnie niejawny członek PZPR, stwierdzał wprost: „Pozwalamy mówić SP, że przyłączą się do SD. W rzeczywistości chodzi o wchłonięcie SP przez nas. W rozmowach zostało wyraźnie zastrzeżone, że nie będzie żadnych kongresów połączeniowych, żadnych manifestacji, nie ma mowy o jakiejkolwiek zmianie nazwy SD" 64 .

W dniu wchłonięcia SP przez SD, demokraci zwiększyli stan organizacyjny w parlamencie o ośmiu posłów, a także liczbę radnych poszczególnych rad narodowych w województwach ${ }^{65}$. W województwie białostockim stało się jednak inaczej. Naciski międzypartyjne koalicjantów (PZPR i ZSL) na SD spowodowały tylko przesunięcie radnych zlikwidowanej partii chrześcijańskiej do MRN bądź WRN w ramach listy radnych - demokratów. Nie uległa więc zmianie jej reprezentacja, ale pozostała na takim samym poziomie ${ }^{66}$.

63 Sktad Naczelnych wtadz SD w latach 1950-1958, w: Stronnictwo Demokratyczne w Polsce Ludowej. Wybór dokumentów z lat 1950-1958, oprac. W. Beczek, Warszawa 1970 , t. I, cZ. 2, s. 470.

64 Cyt. za: A. Andrusiewicz, op. cit., s. 427.

65 Z 12 posłów Stronnictwa Pracy wybranych w styczniu 1947 r. obecna była w Sejmie w dniu połączenia z SD grupa 8 parlamentarzystów. Byli to: Stefan Brzeziński, Kazimierz Gorszyński, Józef Maciejewski, Stanisław Małolepszy, Tadeusz Michejda, Aleksander Olchowicz, Henryk Trzebiński, Antoni Urbanowski. Fakt ten można odnaleźć: Lista postów SD w KRN, Sejmie Ustawodawczym oraz w Sejmach następnych kadencji, w: Stronnictwo Demokratyczne w Polsce Ludowej. Udziat Stronnictwa w pracach parlamentu PRL w latach 1944-1968, oprac. H. Wosiński, Warszawa 1969, cz. 3, s. 21-24. Pozostałe osoby zostały usunięte poprzez przymusową rezygnację, wyjazdy i aresztowania dokonane przez rządzących komunistów. Taki los spotkał chociażby oskarżonych o czynną współpracę z Gestapo i skazanych na dożywotnie więzienie Józefa Kwasiborskiego i Jana Hoppego. Pisze o tym dość szczegółowo: J. Karpiński, Portrety lat: Polska w odcinkach 1944-1989, Londyn 1989, s. 56.

66 APB, Wydział Rad Narodowych SD Wojewódzkiego Komitetu w Białymstoku 1950-1952, sygn. 215: Protokół z posiedzenia Wydziału Rad Narodowych WK SD w Bia- 
Likwidacja białostockiej organizacji wojewódzkiej Stronnictwa Pracy rozpoczęła się w terenie 12 lipca 1950 r., zgodnie z wytycznymi Rady Naczelnej Stronnictwa Demokratycznego. SD powołało wówczas komisję do spraw przejęcia agend i członków chadecji. Cała „akcja scaleniowa” w Białymstoku wraz z podporządkowaniem rzemieślniczego koła szewsko-kamaszniczej spółdzielni pracy „Twórczość” mieszczącej się w lokalu władz wojewódzkich partii chrześcijańskiej przy ulicy Jurowieckiej 12, trwała do 10 grudnia 1950 r. ${ }^{67}$

Przewodniczącym komisji likwidacyjnej został członek prezydium WK SD Jan Olędzki. Towarzyszyli mu: kierownik biura organizacji wojewódzkiej SD Feliks Bowszyc, zastępcy: Wacław Skarżyński i Ewalda Sławińska, członek zwyczajny WK SD Alfons Wojtkowski i II sekretarz Edward Zaleski ${ }^{68}$. Były to osoby ze ścisłego kierownictwa WK SD w Białymstoku, które bezpośrednio nadzorowały rozwiązanie SP. Ugrupowanie chrześcijańskie reprezentowali w tak ważnych momentach: przewodniczący WK SP Feliks Chańko (senior), wiceprzewodniczący komisji rewizyjnej Czesław Fuks oraz członek władz wojewódzkich Wiktor Kobyliński69.

Spośród przejętych przez Stronnictwo Demokratyczne 213 deklaracji członkowskich od byłego Wojewódzkiego Komitetu Stronnictwa Pracy w Białymstoku, kwestionariusze akcesyjne przystąpienia do SD przesłano do 167 chadeków. Trudności w ustaleniu miejsc przebywania oraz zgony członków spowodowały, że niemożliwe było doręczenie pozostałych deklaracji ${ }^{70}$.

łymstoku odbytego w dniu 3.VIII.1950 r., k. 5-6. Typowym przykładem przemieszczenia radnych było odwołanie z WRN radnych SD: Witolda Wenclika i Stanisława Cydzika; a z MRN - radnego z byłego SP - Wiktora Kobylińskiego, wprowadzając go do WRN. Na jego zaś miejsce w MRN wprowadzono z b. SP Stanisława Rogowskiego. Poza tym w WRN byli Feliks Chańko i Kazimierz Surowiński (także z przeszłością chadecką). Informację tę odnaleźć można w: APB, Protokoły posiedzeń Rady Redakcyjnej d/s monografii SD na Białostocczyźnie SD Wojewódzkiego Komitetu w Białymstoku 1977-1978, sygn. 112: S. Bućko, Z. Kummer, L. Siemieniako, Stronnictwo Demokratyczne na Białostocczyźnie w latach 1945-1975, Białystok 1979, k. 51.

67 APB, Protokoły posiedzeń Sekretariatu SD Wojewódzkiego Komitetu w Białymstoku 1951, sygn. 131: Protokół nr 25 z posiedzenia Sekretariatu WK SD w Białymstoku odbytego dnia 12.VII.1951 r., k. 174.

68 APB, Protokoły posiedzeń Sekretariatu SD Wojewódzkiego Komitetu w Białymstoku 1950, sygn. 130: Wniosek Romualda Stankiewicza o powołanie komisji d/s likwidacji i przejęcia majątku po WK SP w Białymstoku, k. 23.

69 A PB, Stronnictwo Demokratyczne..., sygn. 113: E. Szulborski, op. cit., k. 36.

70 Archiwum Akt Nowych w Warszawie (dalej AAN), Protokoły Sekretariatu WK SD w Białymstoku 1950, sygn. 427: Protokół z posiedzenia Sekretariatu WK SD w Białymstoku z dnia 13.IX.1950 r., k. 47. 
Następnie z tej liczby wyselekcjonowano na dalsze rozmowy indywidualne 43 najbardziej „rokujących kandydatów na przyszłych demokratów" 71. Ostatecznie po weryfikacji przez struktury wojewódzkie i centralne SD przy jęto 20 nowych członków.

Tabela 1. Członkowie białostockiego Stronnictwa Pracy, którzy weszli do Stronnictwa Demokratycznego w 1950 r.

\begin{tabular}{|r|l|l|l|}
\hline Lp. & \multicolumn{1}{|c|}{ Nazwisko } & \multicolumn{1}{|c|}{ Imię } & \multicolumn{1}{|c|}{ Zawód } \\
\hline 1. & Chańko & Feliks, senior & urzędnik \\
2. & Chańko & Feliks, junior & technik \\
3. & Czołpiński & Wincenty & szewc \\
4. & Dojlido & Jan & rolnik \\
5. & Domysławski & Wacław & urzędnik \\
6. & Filipowicz & Władysław & metalowiec \\
7. & Foremski & Władysław & fryzjer \\
8. & Fuks & Czesław & kaflarz \\
9. & Horodeński & Konstanty & piekarz \\
10. & Jarmoc & Stanisław & szewc \\
11. & Kloze & Witold & krawiec \\
12. & Kobyliński & Wiktor & kamasznik \\
13. & Korbut & Mikołaj & urzędnik \\
14. & Kowalczuk & Kazimierz & szewc \\
15. & Lewko & Michał & krawiec \\
16. & Rogowski & Stanisław & kamasznik \\
17. & Sawicki & Teofil & urzędnik \\
18. & Stempniak & Franciszek & urzędnik \\
19. & Surowiński & Kazimierz & prawnik \\
20. & Weingarten & Stanisław & urzędnik \\
\hline
\end{tabular}

Źródło autorskie ustalone w oparciu o materiały APB, sygn. 113: E. Szulborski, Stronnictwo Demokratyczne w województwie białostockim w latach 1944-1975, Białystok 1986, w: Aneks 4: Wykaz członków byłego SP, k. 153-160; Także na podstawie listy obecności poszczególnych ogniw organizacyjnych SD.

71 APB, Protokoły z posiedzeń Prezydium SD Wojewódzkiego Komitetu w Białymstoku 1950, sygn. 44: Protokół z posiedzenia Prezydium WK SD w Białymstoku z dnia 28.VIII.1950 r., k. 88. Jednakże to $w$ dokumentacji SD zgromadzonej w Warszawie odnajdziemy z imienia i nazwiska wyselekcjonowaną grupę 43 chadeków zaproszonych na rozmowy do WK SD w Białymstoku. Informacje te odnaleźć można w: AAN, Protokoły z posiedzenia Prezydium WK SD w Białymstoku 1950-1951, sygn. 410: Protokół z posiedzenia Prezydium WK SD w Białymstoku z 28.VIII.1950 r., k. 82. 
Z zamieszczonych w tabeli danych wynika, że do organizacji wojewódzkiej Stronnictwa Demokratycznego w Białymstoku, oprócz jednej osoby, trafili ludzie spełniający wymogi programowe szczególnego oddziaływania demokratów na inteligencję, rzemiosło i prywatną inicjatywę. Byli to przeważnie drobni rzemieślnicy-usługodawcy oraz osoby średniego szczebla urzędniczego. W momencie likwidacji Stronnictwo Pracy liczyło około 17 tysięcy członków. Do SD przystąpiło niecałe 1000 członków, tj. 6\% składu osobowego SP ${ }^{72}$. W Białostockiem chadecja $\mathrm{w}$ okresie wieńczącym jej działalność liczyła prawie $2 \%$ stanu osobowego całego Stronnictwa. Fakty te moga przemawiać za porażką SD, jak i samej istoty „pozyskania” zwolenników społecznej nauki Kościoła katolickiego. Olbrzymia większość chadeków nie podjęła bowiem działalności w nowej przeznaczonej im partii ${ }^{73}$.

Mimo licznych głosów krytycznych w strukturach Stronnictwa Demokratycznego, zaliczono byłym chadekom staż kandydacki w ramach poprzedniej działalności w partii. Od początku byli więc traktowani jako pełnoprawni członkowie SD. W myśl założeń demokratów sam akces SP do SD kończył się dopiero $\mathrm{z}$ chwilą ideologicznego scalenia przyjętych członków i wypracowania nowego podziału w stronnictwie "na osoby aktywne i bierne, zdyscyplinowane i te, które zaliczyć można do grupy rozrabiaczy" 74. Po uzgodnieniu z KW PZPR i WK ZSL do WK SD wprowadzono Feliksa Chańko, Kazimierza Surowińskiego i Wiktora Kobylińskiego. Do prezydium władz miejskich Stronnictwa dołączono Czesława Fuksa, Stanisława Rogowskiego i Stanisława Wiengartena. Siedziba WK SP przy ulicy Jurowieckiej 12 została przekazana przez SD na własność spółdzielni pracy „Twórczość" 75.

Upadek Stronnictwa Pracy zdawał się być nieunikniony od początku legalizacji stronnictwa w systemie partyjnym zapoczątkowanym przez $\mathrm{Ma}$ nifest Lipcowy. Aby zaistnieć w nowej rzeczywistości, SP musiała zgodzić się na dopuszczenie do swoich szeregów ludzi powiązanych z PPR. Tylko kwestią czasu było zahamowanie przez nich bieżącej działalności Stronnictwa. Referendum ludowe z końca czerwca 1946 r. stało się po temu znako-

72 J. Wrona, System..., s. 311.

73 Stronnictwo Demokratyczne w latach 1937-1965, Warszawa 1967, s. 115.

74 L. Chajn, Pod sztandarami Stronnictwa Demokratycznego. Inteligencja i rzemiosto maszeruja do nowych zwycięstw i sukcesów (referat polityczny wygłoszony na Radzie Naczelnej SD w dniu 9.VII.1950 r.), Warszawa 1950, s. 34.

75 APB, Protokoły posiedzeń..., sygn. 112: St. Bućko, Z. Kummer, L. Siemieniako, op. cit., k. 51 . 
mitą okazją. Wszystkie partie polityczne skupione były wówczas na zagadnieniach polityczno-ustrojowych przyszłego oblicza kraju. Ochroną prawną struktur i suwerenności programowej nikt się specjalnie nie przejmował. Historia Stronnictwa Pracy w sposób ostateczny ukazała rzeczywiste intencje komunistów w stosunku do partii politycznych wyznających pluralizm polityczny.

Na Białostocczyźnie wśród istniejących partii politycznych: PPR, PPS, PSL, SL i SD, Stronnictwo Pracy miało najmniejsze znaczenie polityczne. Sytuacja ta wynikała $z$ dość późnego włączenia się w odbudowę ogniw terenowych SP, jak również z pozyskującej ten sam elektorat PSL - programem akceptu jącym niektóre rozwiązania $z$ nauki społecznej Kościoła katolickiego. Od wyborów do Sejmu Ustawodawczego w 1947 r. aż do wchłonięcia, Stronnictwo Pracy było przygotowywane do stopienia się z SD. Moment przymusowego akcesu i nieduża liczba 20 spośród 213 członków przystępujących do partii demokratycznej ukazał rzeczywisty sprzeciw chadeków wobec likwidacji ich ugrupowania. Dał też argument komunistom, że „metoda siłowa" jaką obrali w stosunku do partii chrześcijańskiej nie musi się wcale sprawdzać w stosunku do całego społeczeństwa, a już z pewnością do hierarchii Kościoła katolickiego. 